Halaman 38-44

\title{
Peningkatan Keterampilan Proses Sains Melalui Kegiatan Laboratorium Disertai Strategi Catatan Terbimbing (Guided Note Taking) Pada Siswa Kelas VIII E SMP Negeri 7 Surakarta Tahun Pelajaran 2010/2011
}

\author{
The Enhancement of Science Process Skills through Applying Laboratory Activity \\ with Guided Note Taking on Biology Learning to the Student of VIII E Class \\ at SMP Negeri 7 Surakarta Academic Year 2010/2011 \\ Anggita Widya Nugroho, Meti Indrowati, Bowo Sugiharto \\ Pendidikan Biologi FKIP Universitas Sebelas Maret, \\ Email: metindrowati@yahoo.co.id
}

Diterima 3 Juli 2013, disetujui 7 September 2013

\begin{abstract}
The purposes of this research is to improve the science process skills through applying laboratory activity with guided note taking to the students of VIII E class at SMP Negeri 7 Surakarta, academic year 2010/2011. This research refers to The Classroom Action Research which is conducted in 2 cycles that consist of planning, action, observing, and reflecting. The subject of this research is 36 students of VIII E class at SMP Negeri 7 Surakarta, academic year 2010/2011. The sources of the data consist of information from teachers and students, places and events that happened during the process of teaching and learning, and also some documents/files. The data of this research is collected by using observation sheet, questionnaire, interview, and documentations. The data is analyzed in qualitative descriptive method. The validity of data is tested through method and observer triangulation. The result of this research shows that has done in two cyrcles can be concluded that the application of laboratory activity with guided note taking can improve the science process skills in observe, clasificate, predict, measure, conclude, and communicate skills of the student of VIII E class at SMP Negeri 7 Surakarta, academic year 2010/2011.
\end{abstract}

Key Words: Science Process Skills, Laboratory Activity, Guided Note Taking

\section{Pendahuluan}

Perkembangan ilmu pengetahuan di era globalisasi ini berlangsung semakin cepat dengan diiringi oleh tuntutan untuk memiliki keterampilan yang kompetitif sehingga mampu bersaing dengan yang lain. Berbagai macam keterampilan proses yang dimiliki oleh siswa pada saat pembelajaran nantinya akan menjadi bekal untuk membentuk pribadi yang berkompeten dan mampu bersaing.
Dengan alasan tersebut diperlukan pembelajaran yang mampu untuk mengembangkan aspek-aspek yang terkandung dalam keterampilan proses sehingga bisa diterima dengan baik oleh siswa dan harapannya akan terjadi peningkatan.

Berdasarkan observasi yang telah dilaksanakan terhadap proses pembelajaran mata pelajaran biologi kelas VIII E SMP Negeri 7 Surakarta tahun pelajaran 2010/2011 pada hari Selasa, 1 Februari 2011 menun-jukkan bahwa 
keterampilan proses sains siswa masih rendah. Hal ini dapat dilihat dari 36 siswa yang teliti dalam mengidentifikasi ciriciri suatu objek sebesar $51,43 \%$, siswa yang menggunakan sebanyak mungkin alat indera pada proses pembelajaran sebesar 46,86\%, siswa yang mencatat setiap objek pengamatan mencapai $57,14 \%$, siswa yang memiliki ketelitian untuk menemukan per-samaan atau perbedaan suatu objek sebanyak $51,43 \%$, siswa yang dapat meramalkan sesuatu berdasarkan hubungan antara data/ informasi untuk mengemukakan apa yang mungkin terjadi pada keadaan yang belum diamati sebanyak 50,86\%, siswa yang terampil dalam meng-gunakan alat ukur sebanyak 49,71\%, siswa yang terampil dalam menentukan satuan ukuran suatu objek berdasarkan satuan ukuran yang telah diterapkan sebelumnya sebesar 49,71\%, siswa yang mampu memutuskan keadaan suatu objek atau peristiwa berdasarkan fakta, konsep, dan prinsip yang diketahui sebanyak $57,71 \%$, siswa yang antusias dalam mendiskusikan hasil pengamatan mencapai 58,86\%, siswa yang menyajikan data dari bentuk kalimat ke bentuk lainnya sebanyak $57,14 \%$, siswa yang menyusun laporan hasil pengamatan secara sistematis sebanyak $56,57 \%$, siswa yang dapat menjelaskan hasil pengamatan sebanyak $54,86 \%$.
Pembelajaran yang digunakan belum mengoptimalkan keterampilan proses sains siswa, meskipun sudah dilakukan usaha untuk mengajak siswa untuk terlibat di dalam pembelajaran. Dari siswa sendiri masih ditemukan kegiatan-kegiatan yang tidak termasuk dalam pembelajaran seperti mengobrol dengan teman dan beberapa mengerjakan tugas dari pelajaran lain saat pembelajaran berlangsung.

Menurut hasil penelitian yang dilakukan oleh Haryono (2006: 7), standar pencapaian hasil belajar IPA (sains) $70 \%$, baik dalam hal penguasaan konsep, penguasaan proses, dan sikap sains. Hal ini menunjukkan bahwa hasil belajar IPA dikatakan berhasil atau sudah mencapai target standar jika tiap aspek dan indikator penguasaan proses pembelajaran dan sikap sains siswa dapat mencapai $70 \%$ atau lebih. Sedangkan pada kelas VIII E SMP Negeri 7 Surakarta semua aspek keterampilan proses sains siswa belum dioptimalkan oleh guru.

Berdasarkan permasalahan di atas, dilakukan perbaikan terhadap kualitas proses pembelajaran, khsusnya dalam hal pengembangan keterampilan proses sains siswa dengan penerapan kegiatan laboratorium disertai catatan terbimbing (Guided Note Taking) yang menempatkan siswa sebagai subyek 
belajar dan memberi kesempatan kepada siswa untuk dapat secara bebas mengembangkan keterampilan proses sains.

Kegiatan laboratorium adalah proses pembelajaran yang sifatnya memberikan interaksi langsung yang nyata pada siswa melalui panca inderanya. Hal ini tentunya akan memberikan pengalaman belajar sains yang dapat dirasakan secara langsung. Pada pembelajaran ini memiliki tujuan mengembangkan keterampilan proses, melatih siswa agar bekerja secara cermat dan sistematis, merangsang daya berpikir kritis analisis siswa, mengembangkan sikap ilmiah siswa, mengembangkan aktivitas penalaran secara kritis, serta mengembangkan sikap kejujuran, tanggung jawab, dan mandiri (Wenno, 2008). Dengan kegiatan laboratorium, siswa diharapkan dapat mengembangkan keterampilan observasi, memprediksi, klasifikasi, dan mengukur yang merupakan beberapa aspek yang terkandung dalam keterampilan proses sains.

Strategi Catatan Terbimbing (Guided Note Taking) merupakan salah satu pembelajaran yang menggunakan panduan ringkasan poin-poin utama yang berasal dari materi pembelajaran ditambah dengan modifikasi. Beberapa bagian dari catatan ringkasan yang dianggap penting dibuat diberikan ruangruang kosong yang nantinya akan diisi sendiri oleh siswa. Siswa dapat mengisikan kekosongan materi tersebut dari pembelajaran yang dilakukan. Dengan demikian strategi ini dapat melatih siswa untuk mengasah keterampilan mereka dalam hal mengkomunikasikan dan juga membuat kesimpulan.

\section{Metode Penelitian}

Bentuk penelitian ini adalah Penelitian Tindakan Kelas (PTK) atau Classroom Action Research (CAR) yang bertujuan untuk me-mecahkan masalah yang timbul dalam kelas dan meningkatkan kualitas proses dan hasil pembelajaran di kelas.

Subyek penelitian adalah 36 siswa (16 putra, 20 putri) yang berasal dari kelas VIII E SMP Negeri 7 Surakarta pada semester genap tahun pelajaran 2010/2011.

Prosedur dan langkah-langkah dalam melaksanakan tindakan penelitian terdiri atas rencana (plan), tindakan (act), pengamatan (observe), dan refleksi (reflect). Setelah refleksi akan diikuti dengan perencanaan kembali yang merupakan dasar pemecahan masalah berikutnya.

Permasalahan yang diangkat dalam penelitian ini adalah keterampilan 
proses sains siswa dalam pembelajaran biologi. Upaya untuk mengatasi permasalahan tersebut dilakukan tindakan berupa penerapan kegiatan laboratorium disertai catatan terbimbing (Guided Note Taking). Data penelitian dikumpulkan melalui observasi, angket, dan wawancara. Validasi data dengan menggunakan triangulasi metode dan observer. Analisis data yang digunakan yaitu deskriptif kualitatif yang dilakukan dalam 3 tahapan yaitu reduksi data, penyajian data, dan penarikan kesimpulan.

Penelitian ini dilaksanakan dalam dua siklus, penerapan tahap pembelajaran pada siklus I sama dengan siklus II hanya saja pada siklus II dilakukan tindakan perbaikan sesuai permasalahan yang dikemukakan pada refleksi tindakan pada siklus I. Tindak lanjut pada Siklus II dilakukan agar proses pembelajaran berlangsung lebih maksimal.

\section{Hasil dan Pembahasan}

Hasil Penelitian Tindakan Kelas di kelas VIII E SMP Negeri 7 Surakarta Tahun Pelajaran 2010/2011 menunjukkan bahwa keterampilan proses sains siswa meningkat melalui penerapan pembelajaran kegiatan laboratorium disertai catatan terbimbing. Peningkatan keterampilan proses sains siswa dapat dilihat melalui hasil lembar observasi keterampilan proses sains siswa yang diberikan pada akhir tiap siklus, serta data pendukung berupa hasil angket dan wawancara siswa untuk mengetahui respon siswa terhadap proses pembelajaran kegiatan laboratorium disertai catatan terbimbing.

Berdasarkan analisis pelaksanaan proses pembelajaran pada siklus I diketahui bahwa terjadi peningkatan persentase setiap aspek keterampilan proses sains siswa. Peningkatan ini merupakan efek dari penerapan pembelajaran kegiatan laboratorium disertai catatan terbimbing. Keenam aspek dari keterampilan proses sains siswa pada siklus I telah menunjukkan peningkatan dari pra siklus, meskipun ada aspek yang masih berada di bawah target penelitian. Dari kekurangan yang ada pada siklus I dilakukan refleksi untuk kemudian diperbaiki dan diterapkan pada siklus II. Dari analisis pelaksanaan proses pembelajaran pada siklus II dapat dilihat bahwa keenam aspek keterampilan proses sains siswa telah mencapai target yang ditetapkan sebelumnya. Keenam aspek tersebut diantaranya keterampilan mengamati, mengklasifikasi, mem-prediksi, mengukur, menyimpulkan, dan mengkomunikasikan.

$$
\text { Perbandingan hasil masing- }
$$
masing aspek keterampilan proses sains siswa dari prasiklus, siklus I, dan siklus 
II berdasarkan hasil observasi keterampilan proses sains siswa dapat dilihat pada Gambar 1.

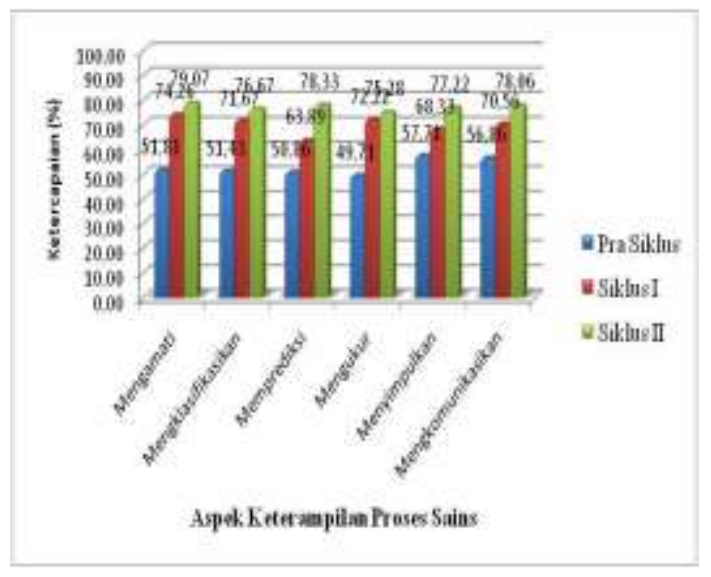

Gambar 1. Diagram Hasil Capaian Setiap Aspek Keterampilan Proses Sains pada Pra Siklus, Siklus I, Siklus II, dan Siklus III

Keterampilan mengamati merupakan keterampilan siswa untuk mengamati objek-objek dan fenomena alam dengan menggunakan pancaindera. Informasi yang diperoleh dapat menuntut keingintahuan, mempertanyakan, memikirkan, melakukan interpretasi tentang lingkungan dan meneliti lebih lanjut. Kemampuan mengamati ini merupakan keterampilan paling dasar dalam proses dan memperoleh ilmu pengetahuan serta hal terpenting untuk mengembangkan keterampilan proses yang lain. Pada saat proses pembelajaran, siswa melakukan keterampilan ini dengan mengamati benda yang menjadi objek percobaan pada kegiatan laboratorium, proses yang terjadi pada saat dilaksanakan percobaan, dan hasil dari percobaan yang mereka lakukan. Dalam hal ini, pada siklus I dilakukan pengamatan terhadap daun yang mereka bawa untuk percobaan Sach, perubahan warna daun saat dilakukan perebusan baik dengan air maupun dengan alkohol, dan warna daun setelah ditetesi dengan larutan iodin. Untuk siklus II, dilakukan pengamatan pada percobaan Ingenhouz terhadap gelembung udara yang muncul pada tabung reaksi, baik untuk tanaman yang diletakkan di tempat terang, tempat gelap, maupun yang diterangi cahaya lampu. Aspek mengamati telah mencapai target yang ditentukan yaitu pada siklus I sebesar $74,26 \%$ dan meningkat pada siklus II menjadi 79,07\% dengan target yang diharapkan $\geq 70 \%$.

Keterampilan mengklasifikasi me-rupakan keterampilan siswa untuk memilah berbagai objek peristiwa berdasarkan sifat-sifat khususnya, sehingga didapatkan golongan/ kelompok sejenis dari objek peristiwa yang dimaksud. Keterampilan mengklasifikasi dapat diketahui berdasarkan kemampuan siswa untuk menggolongkan dan mengamati persamaan, perbedaan dan hubungan serta pengelompokkan objek berdasarkan kesesuaian dengan berbagai tujuan. Siswa belum sepenuhnya menguasai keterampilan ini terlihat pada saat mereka kesulitan dalam membedakan hasil pengamatan pada saat 
praktikum. Kemampuan mengklasifikasi kan yang dilakukan dilakukan siswa pada saat proses pembelajaran diantaranya, pada siklus I setiap siswa diminta untuk membawa daun yang tipis untuk praktikum lalu pada saat praktikum dalam satu kelompok dipilih daun yang paling tipis diantara semua anggota kelompok, selain itu juga diminta untuk membandingkan warna daun hasil percobaan. Pada siklus II siswa diminta untuk membandingkan gelembung hasil percobaan. Aspek mengklasifikasikan telah mencapai target yang ditentukan yaitu pada siklus I sebesar 71,67\% dan meningkat pada siklus II menjadi 76,67\% dengan target yang diharapkan $\geq 70 \%$.

Keterampilan memprediksi merupakan keterampilan dalam membuat ramalan tentang segala hal yang akan terjadi pada waktu mendatang, berdasarkan perkiraan pada pola atau kecenderungan tertentu, atau hubungan antara fakta, konsep dan prinsip dalam ilmu pengetahuan. Pada saat proses pembelajaran, siswa diminta untuk memprediksi hasil praktikum. Namun pada siklus I belum dicapai target yang diinginkan, yaitu sebesar $63,89 \%$. Siswa masih banyak yang belum mengerti tentang keterampilan memprediksi. Disamping itu juga penyampaian dari guru untuk memancing siswa melakukan keterampilan memprediksi juga belum maksimal. Dari hal tersebut, maka pada siklus II guru lebih memperjelas keterampilan memprediksi kepada siswa, bahwa keterampilan memprediksi dilakukan dengan menghubungkan konsep maupun fakta yang ada untuk memperkirakan hal yang akan terjadi. Pada siklus II ini, aspek memprediksi telah mencapai target yang diharapkan yaitu sebesar 78,33\%.

Keterampilan mengukur merupa kan kemampuan siswa dalam membaca suatu ukuran tertenu. Ukuran suatu objek akan dapat diketahui apabila objek tersebut dapat dibandingkan dengan satuan ukuran yang telah ditetapkan sebelumnya. Pada proses pembelajaran siklus I, keterampilan ini dapat dilihat pada saat siswa mengambil air ke dalam gelas kimia yang digunakan untuk merebus daun, mengambil alkohol, serta saat meneteskan larutan iodin pada daun. Untuk siklus II, siswa mengukur banyaknya gelembung yang keluar dalam jangka waktu tertentu. Aspek mengukur telah mencapai target yang diharapkan yaitu pada siklus I sebesar 72,22\% dan meningkat pada siklus II menjadi $75,28 \%$.

Keterampilan menyimpulkan merupakan keterampilan untuk memutuskan keadaan suatu objek atau peristiwa berdasarkan fakta dan konsep yang telah diketahui. Siswa dapat 
mengembangkan keterampilan menyimpulkan apabila mereka mampu menetapkan keadaan suatu objek berdasarkan fakta, konsep maupun prinsip yang mereka peroleh. Pada proses pembelajaran, keterampilan menyimpul kan dibantu oleh catatan terbimbing yang menyajikan beberapa poin penting materi yang dibahas. Dengan demikian, siswa diharapkan akan lebih mudah dalam menarik kesimpulan. Aspek menyimpul kan telah mencapai target yang diharapkan yaitu pada siklus I sebesar $68,33 \%$ dan meningkat pada siklus II menjadi $77,22 \%$

Keterampilan komunikasi merupa kan keterampilan untuk menyampaikan dan memperoleh fakta, konsep, dan prinsip ilmu pengetahuan dalam bentuk suara, visual, atau suara visual. Aspek mengkomunikasikan telah mencapai target yang diharapkan yaitu pada siklus I sebesar 70,56\% dan meningkat pada siklus II menjadi 78,06\%.

\section{Kesimpulan}

Berdasarkan hasil penelitian tindakan kelas yang telah dilakukan sebanyak dua silkus dapat disimpulkan bahwa penerapan pembelajaran kegiatan laboratorium disertai Catatan Terbimbing (Guided Note Taking) dapat meningkatkan keterampilan proses sains untuk aspek mengamati, mengklasifikasi, memprediksi, me-ngukur, menyimpulkan dan berkomunikasi pada siswa kelas VIII E SMP Negeri 7 Surakarta tahun pelajaran 2010/2011.

\section{Daftar Pustaka}

Arikunto, S., Suhardjono, \& Supadi. (2008). Penelitian Tindakan Kelas. Jakarta: Bumi Aksara.

Dimyati \& Mudjiono. (1999). Belajar dan Pembelajaran. Jakarta: PT Rineka Cipta

Haryono. (2006). Model Pembelajaran Berbasis Peningkatan Keterampilan Proses Sains. Jurnal Pendidikan Dasar, 7(1),1-13.

Miles \& Hubberman. (1992). Data Kualitatif. Jakarta: UI Press.

Nur, M. (2011). Modul Keterampilanketerampilan Proses Sains. Surabaya: UNESA.

Silberman, M. (2001). Active Learning 101 Strategi Pembelajaran Aktif. Yogyakarta: Yappendis.

Sutopo, H.B. (2002). Metodologi Penelitian Kualitatif. Surakarta: UNS Press.

Wenno L.H. (2008). Belajar Berbasis Kontekstual Mengajar Sains. Yogyakarta: Inti Media.

Zaini, H., Munthe, B., \& Aryani, S.A. (2007). Strategi Pembelajaran Aktif. Yogyakarta: CTSD. 